\title{
Seasonal Variations in Growth and Physiological Parameters Along with its Relationship with Various Haemato-Biochemical and Mineral Profiles in Black Bengal Goats in Free Range Rearing System
}

By Shagufta Perveen, Pradip Kumar Das \& Syamal Naskar

West Bengal University of Animal and Fishery Sciences

Abstract- Determining animal growth and physiological parameters, their inter-relationship and correlation with various haemato-biochemical and mineral profile during summer and winter seasons in present climatic conditions are imperative for defining genetic potential and adaptation of black Bengal breed for higher meat production. The recorded body weight was found positively correlated with $(P \leq 0.01)$ height, heart girth and, linear length during both summer and winter season, indicating that they can be used to estimate body weight in black Bengal goats of different ages under field conditions where scales are not usually available. The pulse rate was found to be negatively correlated with $(P \leq 0.01)$ body weight during both the summer and winter season. Total erythrocyte count (TEC) was negatively correlated $(P \leq 0.05)$ with the weight during summer but positively $(P \leq 0.01)$ during the winter season.

Keywords: growth, free range system, weight, average weight gain, height, heart girth, linear length, season, summer, winter.

GJMR-G Classification: NLMC Code: WA 360

Strictly as per the compliance and regulations of:

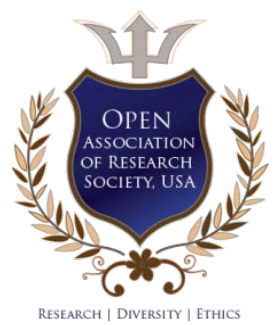

(C) 2020. Shagufta Perveen, Pradip Kumar Das \& Syamal Naskar. This is a research/review paper, distributed under the terms of the Creative Commons Attribution-Noncommercial 3.0 Unported License http://creativecommons.org/licenses/by-nc/3.0/), permitting all non-commercial use, distribution, and reproduction in any medium, provided the original work is properly cited. 


\title{
Seasonal Variations in Growth and Physiological Parameters Along with its Relationship with Various Haemato-Biochemical and Mineral Profiles in Black Bengal Goats in Free Range Rearing System
}

\author{
Shagufta Perveen ${ }^{\alpha}$, Pradip Kumar Das ${ }^{\sigma}$ \& Syamal Naskar ${ }^{\circ}$
}

\begin{abstract}
Determining animal growth and physiological parameters, their inter-relationship and correlation with various haemato-biochemical and mineral profile during summer and winter seasons in present climatic conditions are imperative for defining genetic potential and adaptation of black Bengal breed for higher meat production. The recorded body weight was found positively correlated with $(P \leq 0.01)$ height, heart girth and, linear length during both summer and winter season, indicating that they can be used to estimate body weight in black Bengal goats of different ages under field conditions where scales are not usually available. The pulse rate was found to be negatively correlated with $(P \leq 0.01)$ body weight during both the summer and winter season. Total erythrocyte count (TEC) was negatively correlated $(P \leq 0.05)$ with the weight during summer but positively $(P \leq 0.01)$ during the winter season. Weight and body measurements were negatively correlated ( $\mathrm{P} \leq 0.01$ ) with glucose and total cholesterol during both summer and winter season. $A$ significantly negative correlation was observed between plasma Sodium and body weight gain features during both seasons.
\end{abstract}

Keywords: growth, free range system, weight, average weight gain, height, heart girth, linear length, season, summer, winter.

\section{InTRODUCTION}

T he livestock production system is sensitive to climatic change and at the same time, itself a contributor to the phenomenon. Climate change has the potential to gradually become a more terrifying challenge to the development of the livestock sector in the future. Hence, improvements in productivity and adaptability of natural bio-resources, therefore, need to be achieved with a changing environment. Adaptation to climate change is unlikely to be attained with a single strategy (Hoffmann, 2010). Under field condition, multiple stresses like heat stress, nutritional stress, water stress, etc. occur together and simultaneously affecting

Author a: PhD Scholar. e-mail: sperveen1999@gmail.com

Author б: Professor and HOD Department of Veterinary Physiology, West Bengal University of Animal and Fishery Sciences, 37, K B Sarani, Kolkata - 700037, West Bengal, India.e-mail: pkdaskol@rediffmail.com Author p: Principal Scientist ICAR-IVRI (ERS), Kolkata - 700037, West Bengal, India.e-mail: s_naskar@rediffmail.com body weight, respiratory rate, pulse rate, rectal temperature, hemoglobin, packed cell volume, glucose, total protein, cortisol (Sejian et al., 2013). High environmental temperature exerts a negative influence on the performance of the livestock population (Liu et al., 2011).

In present changing climatic conditions, the study of growth dynamics is of significance as the demand for meat is always increasing. The growth determines the meat-producing ability up to a marketable age, i. e., six months. Goats are known for their wide adaptability, disease resistance (Banerjee, 2007). Goat is a valuable and promising livestock species mainly for meat production around the world (Barkley et al., 2012). Due to its multifactorial abilities like low body mass, and low metabolic requirements, the goats, are regarded as an asset in climate-resilient agricultural system (Silanikove, 2000).

Hence, the study of growth dynamics up to puberty in goats is therefore vital because it can help to accurately and judge for the rate of response of young kids to the environment, particularly in present climatic conditions. Studies of different growth phases are expensive and exhaustive. But it can bring more information about the adaptation rate and or rate of response of breed under changed environmental conditions. Continuous and patient research is required to define mechanisms controlling the growth and production of animals to improve the efficiency of producing food from them. This type of research is the need of time as we can prepare our self for future challenges.

So, the present study aimed to access the growth pattern of kids during summer and winter season about its' physiological responses, haematobiochemical and minerals parameters maintained in free-range rearing system and to use it as a base or platform for further study. The data generated will serve as a guide to the physiological characterization and helps in the interpretation of climatic influence on 
productivity. The attempt will help to refine strategies for goat improvement in the future.

\section{il. Materials and Methods}

a) Description of the study area and period of study

The study was carried out at the Indian Council of Agriculture Research-Indian Veterinary Research Institute, Eastern Region Station at Kalyani Goat Farm of Nadia district, West Bengal, India. The place falls in the lower Gangetic Plain Region of India. Summer and Winter season were considered for the study. The environmental temperature was $38.79 \pm 3.44{ }^{\circ} \mathrm{Cin}$ summer and $14.98 \pm 4.64{ }^{\circ} \mathrm{C}$ in winter. Relative humidity was $64.36 \%$ and $57.86 \%$ in summer and winter, respectively. Johanson et al. (1963) formula was used for Temperature Humidity Index (THI) calculation. The $\mathrm{THI}$ value was maximum during May $(\mathrm{THI}-86.68)$ and minimum during January (THI - 67.96).

\section{b) Experimental animals and their management}

Birth season was used for the selection of experimental kids [Summer born kids ( $n=50$, male: 25 , female: 25) and Winter born kids ( $n=50$, male: 25 , female: 25)]. The growth parameters like body weight, height, heart girth, and linear length in all these kids were recorded. To study blood parameters, twenty-four kids were selected [Summer born male kids $(n=6)$, Summer female kids $(n=6)$, Winter male kids $(n=6)$, and Winter female kids $(n=6)$ ]. All kids were maintained under a free-range rearing system and were fed only with mother's milk up to weaning. Vaccination and deworming schedule followed in experimental animals were as per standard schedule. Each animal was turned out for natural grazing in the morning (8.00 am to 12.30 $\mathrm{pm})$ and again in the afternoon (2.30 pm to $5.30 \mathrm{pm}$ ).

\section{c) Blood sample collection}

Blood samples (5 ml/animal) were collected in heparinized vacutainer from the jugular vein at day $15^{\text {th }}$, $30^{\text {th }}$ (1 Month), 60 $0^{\text {th }}$ (2 Month), 90 $0^{\text {th }}$ (3 Month), $120^{\text {th }}$ (4 Month), $150^{\text {th }}$ (5 Month) and180 th $(6$ Month) age considering day zero as the day on which the kid was born. The blood samples were put in an ice bucket and carried to the laboratory directly for further processing. The hematological analysis was immediately completed after blood sample collection and the rest portion was subjected to centrifugation at 3000 completed rpm for 30 minutes for separation of plasma. Frozen plasma was kept at $-20^{\circ} \mathrm{C}$ till further analysis.

\section{d) Growth Parameters}

The weights of kids were measured as soon as the kids got cleaned and dried immediately after birth. Subsequently, body weights were recorded as per schedule from each animal in the morning before feeding and watering. Weighing machine (Balance Avery, Bombay, India) was used to record weight of the kids by subjecting them to stand individually. Weight and weight gain were expressed respectively in $\mathrm{Kg}$. and gram. Linear-length, heart girth, and height of the animal were measured by measuring tapes in centimetre.

\section{e) Physiological Parameters}

Digital thermometer (Hicks Thermometer), was used for recording rectal temperature by placing the thermometer in contact of rectal mucosa until the reading stabilizes. The femoral artery was used for pulse rate per minute recording. Respiration rate per minute of each of the animals was recorded by visual observations of in ward, and outward abdominal movement. Counting of one inward and outward movement as one respiration was made and respiration rate was expressed in numbers per min.

\section{f) Hematological Parameters}

For hematological study all standard procedures were followed (Hemoglobin, Packed Cell Volume, Total Erythrocyte Count, Total Leukocyte Count).

\section{g) Biochemical Parameters}

All biochemical parameters (Total Protein, Albumin, Globulin, Total Cholesterol, Aspartate amino transferase and Alanine transaminase) were measured using commercially available kits specific for goats. For the determination of plasma NEFA, the Copper Soap Extraction Method modified by Shipe et al. (1980) and Good win (1968) method for Alpha-amino nitrogen was adopted.

\section{h) Mineral Parameters}

The method of Fernandez and Kahn (1971) was used for Plasma electrolytes viz. Sodium, Potassium, Calcium, and Iron estimation in atomic absorption spectrophotometer (Thermo fisher Scientific, ICE 3000 Series).

\section{i) Statistical Analysis}

Appropriate statistical analysis for the experimental data was adopted by using the method described by Snedecor and Cochran (1967) by using the software IBM-SPSS (version 20.0). For all variables under study, General Linear Model technique repeated over age-groups and seasons was considered.

\section{Results And Discussion}

\section{a) Weight gain features}

The alterations in the growth parameters of the experimental kids of both seasons during different periods of pre-pubertal growth have been presented in Table 1. The kids born in winter achieved significantly ( $P$ $\leq 0.01)$ higher body weight $(8.19 \pm 0.30 \mathrm{Kg}$ at 180 days) compared to the kids born in summer (7.95 \pm $0.32 \mathrm{Kg}$ at 180 days). The kids born in winter (39.64 \pm $2.46 \mathrm{~g} /$ day) were having $12 \%$ more body weight gain compared to summer $(35.32 \pm 2.07 \mathrm{~g} /$ day $)$. There was no or little variation between the heart girth and season. 
No seasonal variation was observed in respect of height and linear length.

The weight gain featured in the study was close to the report of Singh et al. (2000) and more than that of Bera et al. (2008). Earlier Yusuff et al., 1981; Khanal et al., 2005 and Marai et al., 2007 also reported the effect of season on the growth. In this investigation, the kids born in winter gained maximum body weight than that of the summer-born kids. It may be because of the fact that environmental temperature, as well as THI during summer, reduces the feed intake, which adversely affects the weight gain (Husain et al., 1996; Khanal et al., 2005 and Marai et al., 2007). Sharma et al. (1998) also reported that factors such as forage availability, environmental stress such as heat and rain might modify the feeding pattern in goats.

\section{b) Physiological Responses}

Table - 2 present the mean of the rectal temperature, respiration rate, and pulse rate at different ages during summer and winter seasons. Rectal temperature was significantly $(P \leq 0.01)$ more in the kids born in summer $\left(39.34 \pm 0.09^{\circ} \mathrm{C}\right)$ than winter $(38.68$ $\pm 0.06^{\circ} \mathrm{C}$ ). The respiration rate was significantly $(\mathrm{P} \leq$ $0.01)$ more in the kids born in summer $(19.20 \pm 0.20 /$ min) than winter $(12.96 \pm 0.20 / \mathrm{min})$. The pulse rate was significantly $(P \leq 0.01)$ more in the kids born during summer (111.74 $\pm 0.84 / \mathrm{min})$ than winter (107.50 \pm $1.05 / \mathrm{min})$.

Body temperature is one of the best indicators of heat tolerance, which represents the thermoregulatory mechanisms in terms of all heat gain and heat loss of the body. Rectal temperature is considered as an index of body temperature even though there is a considerable variation in different parts of the body core at several times of the day (Srikanda kumar et al., 2003). The metabolic responses that occur during the transition from fetal to neonatal life present a change from a thermoregulatory state in which inhibitory stimuli dominate (Ball et al. 1995). Thermo regulatory process in terms of birth weight is reported in sheep, and they suggested that lighter lambs at birth have reduced the capability to sustain body temperature (Alexander, 1975; Dwyer, 2008).

In this investigation, we found that kids born in summer exhibited higher rectal temperature compared to the kids born in winter. The rectal temperature of goats elevated with high environmental temperature is reported by many workers (Devendra, 1987; Marai et al., 2007). Stress-induced hyperthermia has been reported in goats (Bouwknecht et al., 2007) and associated with an activation of the hypothalamic-pituitary-adrenal axis as well as the sym patho-adrenal system (Groenink et al., 1994).

Also, it was found that the kids born in summer have a higher pulse rate compared to the kids born in winter. Ambient temperature has a significant relationship with the respiratory and pulse rate fluctuations as it is a physiological mechanism against elevated heat load (Banerjee et al., 2014).An increase in pulsation rate increases blood flow from the core to the surface as a result of it more heat is lost (Marai et al., 2007). The increase in cardiac output and cutaneous blood flow by heat stress, due to blood redistribution from deep splanchnic to more peripheral body regions, have been implicated in goat (Silanikove, 2000)

In our study, kids born in summer exhibited a higher respiration rate compared to the kids born in winter. Respiration is the main route of evaporative heat loss of goat through the respiratory tract (Gall, 1991) as sweating is not a channel of heat loss in goat (Devendra and Burns, 1988. Therefore, an increase in respiratory rate aids in heat dissipation via evaporative cooling also reported with a rise in ambient temperature (Blackshaw and Blackshaw, 1994). Blight (1985) stated that a daily change in respiration rate per minute from the effect of environmental temperature might not be parallel with the change in body temperature and pulsation number.

\section{Relationship of Body Weight Gain FeATURes With HaEMATO-Biochemical and Mineral Parameters During Summer and Winter Season}

\section{a) Physiological parameters}

Table $-3 \& 4$ present the correlation coefficients between body weight gain features and physiological responses of black Bengal goat during summer and winter. Height, heart girth, and linear length was positively correlated with Weight $(P \leq 0.01)$ during both summer and winter season. Positive correlation $(P \leq$ 0.01) was observed between respiration rate and body weight, body measurements, and rectal temperature only during the summer season. Whereas negative relation $(P \leq 0.01)$ of the pulse rate with body weight during both the summer and winter season was observed.

The results of the present study related to the correlation between pulse rate and post-natal growth are similar with the findings of Piccone et al. (2006) and Ocak et al. (2009). In the present investigation all the growth parameters viz. body weight, height, heart girth, and linear length were positively correlated among themselves which was in agreement with the earlier reports in cattle (Udeh et al., 2011and Olutogun et al., 2003) and goats and sheep (Ozoje and Herbert, 1997; Ogungbayi et al., 2003). Hence, these parameters can be used to measure the growth rate in goats. These parameters have a strong genetic correlation with body weight and is useful for genetic selection (Magnabosco et al., 2002). Olutogun et al. (2003) also reported that body size and height were complementary, and the growth is a function of length, height, and circumference. Ocak et al. (2009) reported a positive 
correlation between growth parameters and zero between growth and thermo-physiological parameters in Saanen kids.

\section{b) Haematological Parameters}

Weight and measurements were positively correlated $(P \leq 0.01)$ with hemoglob in and packed cell volume (PCV) during both seasons. Total erythrocyte count (TEC) was negatively correlated $(P \leq 0.05)$ with weight during summer but positively $(P \leq 0.01)$ during the winter season.

The presence of positive correlations between body weight and hemoglobin, PCV, may be regarded as an outcome of a faster rate of erythrocyte production along with earlier rate of saturating them with hemoglobin. It be associated with the urgent need to enhance oxygen- carrying capacity, i. e., intensifying use of hemoglobin as a vehicle for oxygen transport for growing kids. High PCV hematocrit values indicate either an increase in the number of circulating RBC or a reduction in circulating plasma volume (Banerjee, 2007). Bentrick., 1974 reported that hematological parameters particularly, PCV and $\mathrm{Hb}$, were associated with the nutritional status of the animal. However, the main functions of the erythrocyte are to serve as a carrier of hemoglobin. A positive relation of $\mathrm{Hb}$ and PCV values observed in this study might likely be a sign of healthier goats. The presence of positive correlation between TEC and body weight during the winter season may be associated with the improvement of the nutritional status of goats. At the same time the negative association between TEC and weight during summer may be related to a decrease of thyroid hormone secretion, which is related to declining the process of erythropoiesis.

\section{c) Biochemical Parameters}

Weight and body measurements were negatively correlated $(P \leq 0.01)$ wi th glucose and total cholesterol during both summer and winter season. The correlation pattern in cholesterol concentration may be due to the high intake of dietary fat provided by colostrum and milk.

Weight and body measurements were positively correlated $(P \leq 0.01)$ with Alanine Amino transferase, Aspartate Amino trans ferase, $\alpha$-Amino Nitrogen, and Non-esterified Fatty Acids during both summer and winter season. The increase in the activities of Alanine Amino transferase and Aspartate Amino transferase with growth parameters in plasma is mainly due to the leakage of these enzymes from the liver cytosol into the blood (Shakoori et al., 1994), which reflects active liver function with growing age. Blood $\alpha$-Amino Nitrogen is an indicator of the protein synthesis status of the animal. The findings of the present study are supported by Hornick et al., 1996 and 1998; Mondal and Prakash, 2004. They also reported that plasma $\alpha$-Amino Nitrogen increases during growth and stabilizes or decreases after completion of an active phase of growth. Hornick et al. (1998) reported that rapidly growing beef cattle had more plasma $\alpha$-Amino Nitrogen.

Many studies have shown a good correlation between energy balance and Non-esterified Fatty Acids concentration (Kartiarso et al., 1989; Yelich et al., 1996). The Concentration of Non-esterified Fatty Acids directly reflects the amount of adipose tissue breakdown in response to negative energy balance. Circulating Nonesterified Fatty Acids are absorbed and metabolized for energy by the liver and other tissues. Clinical experiences suggest serum Non-esterified Fatty Acid concentration be more sensitive to energy balance change compared with body scoring in growing situations (Van Saun, 2000). The physiological response, $s$ and blood metabolites result of the kids during prepubertal growth and their energy balance showed that growth have a profound effect on some biochemical parameters (Nazifi et al., 1999).

\section{d) Plasma Minerals}

The seasonal variation existed $(P \leq 0.01)$ in sodium, potassium, and calcium. The reduction of plasma potassium during summer may be due to loss of potassium in sweats. El-Nouty et al. (1980) also reported decline in plasma sodium and potassium level during heat stress. Orden et al. (1999) also informed that there was no significant difference with seasons in iron level in goat blood.

Plasma sodium and body weight gain features were significantly negative correlated during both seasons. The association among the minerals and body weight gain features can be inferred by different reasons. Blood Sodium concentrations in small ruminants is often used as an indicator of animal mineral status (McDowell, 2003). Calcium is involved in the synthesis of steroid hormones in ovaries and adrenal glands and the release of luteinizing hormone from the pituitary gland (Harvey et al., 1987). Calcium is essential for bone formation in growing neonates, and the positive correlation is probably due to growth and milk intake (Herosimczyka et al., 2011).

\section{Simple Regression Equations}

The Simple Regression equations between age as the independent variable and other dependable variables during summer and winter season is presented in Table $-5 \& 6$, where also, negative relationship between blood glucose, total plasma cholesterol, plasma sodium, and age was found during both the seasons and pulse rate during winter only. At the same time all other parameters showed a positive relationship with the age during both summer and winter season.

Determined significant relationship of most parameters in blood of growing kids suggests an association between these indicators, particularly 
metabolites involved in the metabolism of fats, proteins, and minerals during the entire process of the growth.

\section{Conclusion}

The findings of the present investigation not only substantiated the earlier findings but also help to assess the growth performance of black Bengal kid under free-range system during summer and winter season. Rapid growth during the pre-pubertal period can minimize the cost of rearing, thus providing more profit to the farmer. These data can be used in growth evaluation, improving management practices, nutrition, and health monitoring. The information on different growth parameters as an outcome of the investigation will undoubtedly help the stakeholder as well as planners to implement successful goat rearing practices.

\section{Vil. Disclosure Statement} the authors.

No potential conflict of interest was reported by

\section{ACKNOWLEDGEMENT}

Authors acknowledge the Indian Council of Agricultural Research-Indian Veterinary Research Institute (Eastern Region Station) for providing the experimental animals. Authors are also thankful to the Hon'ble Vice Chancellor of the West Bengal University of Animal and Fishery Sciences for providing support to conduct the study.

\section{References Références Referencias}

1. Alexander G. 1975. Body temperature control in mammalian young. British Medical Bulletin31: 62-68.

2. Ball KT, Gunn R, Power G, Asakura $H$ and Gluckman P D. 1995. A potential role of adenosine in the inhibition of nonshivering thermo genesis in the fetal sheep. Pediatric Research 37: 303-309.

3. Baneejee, G. C. 2007. A Textbook of Animal Husbandry. 8th Edn. Published by Raju Primlani for Oxford and IBJ publishing Co. PVT Ltd, New Delhi. 1079.

4. Banerjee D, Upadhyay R C, Chaudhary U B, Kumar R, Singh S, Ashutosh, Das T K and De S. 2014. Seasonal variations in physio-biochemical profiles of Indian goats in the paradigm of hot and cold climate, Biological Rhythm Research46: 221-236.

5. Barkley, M. E., Knoll, K., Kime, L. F., and Harper., L. K. 2012. Meat Goat production, Penn State Extension, The Pennsylvania State University 2012.

6. Bentrick S. 1974. Haematology, Textbook of Veterinary Pathology. Publ. Williams and Co Baltimore, 217-224.

7. Bera S, Samonta A, Santra A and Maiti S. 2008. Effect of Breeding Practice and Sex on Growth of Black Benegal Goats under Village conditions of
West Benegal. Online Veterinary Journal. Volume 3 (1) article \# 23.

8. Blackshaw, J. K. and Blackshaw. A. W. 1994. Heat stress in cattle and the effect of shade on production and behaviour: a review. Australian Journal of Experimental Agriculture 34(2)285-295.

9. Blight, J. Temperature regulation. Stress Physiology in Livestock. I. Basic Principles. 1985 CRF Press, USA, p. 75-79.

10. Bouwknecht, J. A., B. Olivier and R. E. Paylor, 2007. The stress-induced hyperthermia paradigm as a physiological animal model for anxiety: A review of pharmacological and genetic studies in the mouse. Neuroscience and Biobehavioral Reviews. 31: 47-59.

11. Devendra, C. and M. Burns. 1983. Goat Production in the Tropics. Commonwealth Agricultural Bureaux, Franham House, Franham Royal, Slough SL2 3BN. UK.7.

12. Devendra, C., 1987. Goats. Ed. Johnson H.P. Bioclimatology and the Adaptation of Livestock. Elsevier Publ., 157, Holland, p. 16-7.

13. Dwyer, C. M. 2008. The welfare of the neonatal lamb. Small Ruminant Research 76: 31-41.

14. El- Nouty FD, Elbanna IM, Davis TP, Johanson HD.1980. Aldosterone and ADH response to heat and dehydration in cattle. Journal of Applied Physiology. 48: 249-255.

15. Fernandez FJ, Kahn HL. 1971. Clinical method for atomic absorbtion spectroscopy. Clin. Chem. Newsl. 3: 24-28.

16. Gall, G. F. 1991. Breed differences in adaptation of goats. In: In World Animal Science: Genetic Resources of Pig, Sheep and Goat (Ed. K. Maijala). Royal Veterinary and Agricultural University, Denmark. Elsevier Science Publishers B.V. Amsterdam. 413-430.

17. Goodwin JF. 1968. The Colorimetric Estimation of Plasma Amino Nitrogen with DNFB. Clin. Chem.14 (11): 1080-1090.

18. Groenink, L., J. Van Der Gugten, T. Zeth of, J. Van Der Heyden and B. Olivier, 1994. Stress-induced hyperthermia in mice: hormonal correlates. Physiology and. Behaviour. 56: 747-749.

19. Harvey, J. W., Asquith, R. L., Sussman, W. A., Kivipel to, J. 1987 Serum ferritin serum iron and erythrocyte values in foals. Ammerican Journal Veterinary Research. 48, 1348-52.

20. Herosimczyka, Lepczynskia., Dratwahalupnika., Kurpinskaa., Klonowskaa., Skrzypczak W F. 2011. Age-related changes of selected blood biochemical indicators in dairy calves during their first week of life. Folia Biological (Krakow). 59, 25-30.

21. Hoffman, I. 2010. Climate Change and the characterisation, breeding and conservation of animal genetic resources. Animal Genetics, 41(1): 32-46. 
22. Hornick, J. L., Eenaeme, C. V. Gauthier, S., Baldwin, P. \& Istasse, L.1996. Glucose, alpha- amino nitrogen and amino acid exchange across the hind limb in young double muscled type bulls maintained at two growth rates. Canadian Journal of Animal Sciences, 76(2):193-202.

23. Hornick, J. L., Eenaeme, C. V., Diez, M., Minet, V.. \& Istasse, L. 1998. Different periods of fed restriction before compensatory growth in Belgiam Blue bulls: 11. Plasma metabolites \& hormones. Journal of Animal Sciences, 76:260-271.

24. Husain SS, Horst P and Islam ABMM. 1996. Study on the growth performance of Black Bengal goat in different periods. Small ruminant research21: 165171.

25. Johanson HD, Ragsdale AC, Berry IL. Shanklin MD. 1963. Temperature- humidity effects including influence of acclimation in feed and water consumption of Holstein cattle. Missouri Agriculture Express Research Bulletin. 846.

26. Kartiarso, M., Martin, D. And Teleni, E. 1989. The pattern of utilisation of body fat reserve by working cattle and buffalo. DAP Project Bull, 8:7-8.

27. Khanal, R. C., D.P. Rasali, T. S. Dhaubhadel, B. R. Joshi and N. P. S. Karki, 2005. Comparative performance of indigenous Khari and Khari $X$ Sinhal goats raised on-station in Nepal Journal of Biological Sciences., 5(2): 124-28.

28. Liu, Y., Li, D., Li, H., Zhou, X. and Wang, G.A. 2011. Novel SNP of the ATP1A1 gene is associated with heat tolerance traits in dairy cows. Molecular Biology Reports. 38: 83-88.

29. Magnabosco C D U, Ojala M, De Los Reyes A, Sainz R D, Fernandes A and Famula T R. 2002. Estimates of environmental effects and genetic parameters for body measurements and weight in Brahman cattle raised in Mexico. Journal of Animal Breeding and Genetics. 119: 221-228.

30. Marai IFM, El Darawany AA, Fadiel A, Abdel Hafez MAM. 2007. Physiological traits as affected by heat stress in sheep a review. Small Ruminant Research. 71: 1-12.

31. McDowell, L. R. 2003. Minerals in Animal and Human Nutrition. $2^{\text {nd }}$ edn, 644 pp. Elsevier Science, Amsterdam.

32. Mondal, M. and Prakash, B. S. 2004. Changes in plasma nonesterified fatty acids (NEFA), glucose and alpha- amino nitrogen and their relationship to body weight and plasma growth hormone $(\mathrm{GH})$ in growing buffaloes (Bubalus bubalis). Journal of Animal Physiology and Nutrition. 88(5-6): 223-8.

33. Nazifi,S., Gheisari, H., Poorabbas, H. 1999. The influence of thermal stress on serum biochemical parameters of dromedary camels and their correlation with thyroid activity. International journal of Heamatology. 9:49-53.
34. Ocak, S. Onder, H. and Guney, O. 2009. Thermophysiological responses and some growth parameters in kids. During the first 45 days under Mediterrean climate conditions in Turkey. Journal of Animal and Veterinary Advances. 8(6): 1237-1241.

35. Ogungbayi A T Abiola S S and Ozoje M O. 2003. The study of linear body measurements of West African Dwarf (WAD) lambs and kids under traditional management system. Nigeria Journal of Animal Production. 30(2): 197-202.

36. Olutogun O. Abdullah, A. R. Raji A. O., Adetoro P. A. and Adeyemi A. 2003. Body conformation characteristics of white Fulani and Gudali (zebu) cattle breeds of Nigeria. Proceeding 28th Annual Conference, Nigeria Society for Animal Production. 28: 129-132.

37. Orden, E. A., Serra, A. B., Serra S. D, Aganon, C. P., Cruz, E. M., Cruz, L. C and Fujihara, T.1999. Mineral concentration in blood of grazing and some forage in Lahar- Laden area of central Luzon, Philipines, Asian Austral Journal of Animal Sciences. Vol 12, No3: 422-428.

38. Ozoje M. O. and Herbert U. 1997. Linear measurements in West African Dwarf (WAD) and Red Sokoto goats. Nigerian Journal of Animal Production. 24(1): 13-18.

39. Piccione, G., M. Borruso, F. Fazio, C. Giannetto and G. Caola. 2006. Physiological parameters in lambs during the first 30 days postpartum. Small Ruminant Research 72:57-60.

40. Sejian, V., Maurya, V. P., Kumar, K. And Naqvi, S. M. K. 2013. Effect of multiple stresses on growth and adaptive capability of Malpura ewes under semi- arid tropical environment. Tropical Animal Health Production. 45: 107-116.

41. Shakoori, A. R., Butt, U., Riffat, R. and Aziz, F. 1994. Hematological and biochemical effects of danitol administered for two months on the blood and liver of rabbits. Zeitschriftfur Angewandte Zoologie, 80: 165-180.

42. Sharma, K., Saini, A. L., Singh, N. and Ogra, J. L. 1998. Seasonal variations in grazing behaviour and forage nutrient utilisation by goats on a semi-arid reconstituted silvipasture. Small Ruminant Research., 27: 47-54.

43. Shipe, W. F., Senyk, G. F. and Fountain, K. B. 1980. Modified copper soap extraction methods for measuring free fatty acids in milk. Journal of Dairy Sciences. 63(2): 193-198.

44. Silanikove N. 2000. The physiological basis of adaptation in goats to harsh environments. Small Ruminant Research. 35: 181-193.

45. Singh, D. K. and Singh, N. S. 2000. Genetic analysis of pre and post-weaning growth traits of black Bengal kids. Indian Veterinary Medical Journal, 24: 275-278. 
46. Snedecor, G. W. and Cochran, W. G. 1967. Statistical Methods. 8th Ed, lowa state university, Press, USA.

47. Srikandakumar A, Johnson E H and Mahgoub O. 2003. Effect of heat stress on respiratory rate, rectal temperature and blood chemistry in Omani and Australian Merino sheep, Small Ruminant Research 49: 193-198.

48. Udeh I., Akpororo P. O. and Onogbe C. O. 2011. Phenotypic correlations among body measurements and physiological parameters in Muturu and Zebu cattle. ARPN Journal of Agricultural and Biological Science. 6(4): 1 - 4.

49. Van Suan, R. J. 2000. Blood profiles as indicators of nutritional status. Department of large animals.
Clinical Sciences, Colleges of Veterinary Medicines, Oregon.

50. Yelich, J. V., Wettermann, R. P., Marston, T. T. and Spicer, L. J. 1996. Luteinizing hormone, growth hormone, insulin like growth factor- I, Insulin and metabolites before puberty in heifers fed to gain at two rates. Domestic animal Endocrinology, 13: 325-338.

51. Yusuff, M. K., Sulaiman, A. W. and Ohtman, A. S. H. 1981. Comparative pre-weaning growth performance of crossbred kids. Malaysian Veterinary Journal, 7(2): 29-36.

Tables

Table 1: Mean with standard error of Growth parameters of Summer and Winter born black Bengal goats during prepubertal growth period

\begin{tabular}{|c|c|c|c|c|c|c|c|c|c|c|}
\hline Parameters & Sex & G1 & G2 & G3 & G4 & G5 & G6 & G7 & Overall & $P$ value \\
\hline \multirow{2}{*}{$\begin{array}{l}\text { Body Weight } \\
\text { (Kg) }\end{array}$} & Summer & $\begin{array}{c}1.60 \\
\pm 0.06\end{array}$ & $\begin{array}{c}2.21 \\
\pm 0.16\end{array}$ & $\begin{array}{c}3.07 \\
\pm 0.22\end{array}$ & $\begin{array}{c}4.59 \\
\pm 0.25\end{array}$ & $\begin{array}{c}6.17 \\
\pm 0.36\end{array}$ & $\begin{array}{c}6.99 \\
\pm 0.34\end{array}$ & $\begin{array}{c}7.95 \\
\pm 0.32\end{array}$ & $\begin{array}{l}4.65 y \\
\pm 0.27\end{array}$ & \multirow{2}{*}{$\begin{array}{c}0.00^{\star *} \\
\text { (between } \\
\text { Season) }\end{array}$} \\
\hline & Winter & $\begin{array}{c}1.70 \\
\pm 0.05\end{array}$ & $\begin{array}{c}2.52 \\
\pm 0.18\end{array}$ & $\begin{array}{c}3.38 \\
\pm 0.28\end{array}$ & $\begin{array}{c}5.20 \\
\pm 0.21\end{array}$ & $\begin{array}{c}6.49 \\
\pm 0.36\end{array}$ & $\begin{array}{c}7.38 \\
\pm 0.32\end{array}$ & $\begin{array}{c}8.19 \\
\pm 0.30\end{array}$ & $\begin{array}{l}4.98 x \\
\pm 0.27\end{array}$ & \\
\hline \multirow{2}{*}{$\begin{array}{l}\text { Weight Gain } \\
\text { (gm/day) }\end{array}$} & Summer & $\begin{array}{r}34.83 \\
\pm 2.97\end{array}$ & $\begin{array}{l}20.44 \\
\pm 4.22\end{array}$ & $\begin{array}{l}28.72 \\
\pm 4.43\end{array}$ & $\begin{array}{l}50.61 \\
\pm 7.00\end{array}$ & $\begin{array}{c}52.53 \\
\pm 4.76\end{array}$ & $\begin{array}{l}28.19 \\
\pm 4.40\end{array}$ & $\begin{array}{l}31.75 \\
\pm 3.13\end{array}$ & $\begin{array}{l}35.32 y \\
\pm 2.07\end{array}$ & \multirow[b]{2}{*}{$\begin{array}{c}0.00^{\star \star} \\
\text { (between } \\
\text { Season) }\end{array}$} \\
\hline & Winter & $\begin{array}{l}55.94 \\
\pm 5.41\end{array}$ & $\begin{array}{l}27.42 \\
\pm 4.81\end{array}$ & $\begin{array}{l}29.53 \\
\pm 4.58\end{array}$ & $\begin{array}{l}60.86 \\
\pm 6.46\end{array}$ & $\begin{array}{r}44.39 \\
\pm 6.99\end{array}$ & $\begin{array}{c}30.33 \\
\pm 5.72\end{array}$ & $\begin{array}{l}29.03 \\
\pm 3.88\end{array}$ & $\begin{array}{l}39.64 x \\
\pm 2.46\end{array}$ & \\
\hline \multirow{2}{*}{$\begin{array}{l}\text { Height } \\
(\mathrm{cm})\end{array}$} & Summer & $\begin{array}{l}24.58 \\
\pm 0.38\end{array}$ & $\begin{array}{l}28.75 \\
\pm 0.66\end{array}$ & $\begin{array}{l}38.42 \\
\pm 0.87\end{array}$ & $\begin{array}{l}36.50 \\
\pm 0.52\end{array}$ & $\begin{array}{c}36.42 \\
\pm 0.60\end{array}$ & $\begin{array}{l}39.75 \\
\pm 0.80\end{array}$ & $\begin{array}{l}40.67 \\
\pm 0.89\end{array}$ & $\begin{array}{l}34.44 \\
\pm 0.65\end{array}$ & \multirow{2}{*}{$\begin{array}{c}\text { 0.14(between } \\
\text { Season) and } \\
0.0{ }^{*} \\
\text { (between } \\
\text { Summer, } \\
\text { Winter) } \\
\end{array}$} \\
\hline & Winter & $\begin{array}{l}27.00 \\
\pm 0.55\end{array}$ & $\begin{array}{l}29.17 \\
\pm 1.02\end{array}$ & $\begin{array}{l}32.17 \\
\pm 0.77\end{array}$ & $\begin{array}{l}35.92 \\
\pm 0.50\end{array}$ & $\begin{array}{l}39.00 \\
\pm 0.80\end{array}$ & $\begin{array}{l}39.00 \\
\pm 0.75\end{array}$ & $\begin{array}{l}41.25 \\
\pm 0.85\end{array}$ & $\begin{array}{l}34.79 \\
\pm 0.62\end{array}$ & \\
\hline \multirow{2}{*}{$\begin{array}{l}\text { Heart Girth } \\
\quad(\mathrm{cm})\end{array}$} & Summer & $\begin{array}{l}26.08 \\
\pm 0.36\end{array}$ & $\begin{array}{l}31.50 \\
\pm 0.49\end{array}$ & $\begin{array}{l}39.50 \\
\pm 0.71\end{array}$ & $\begin{array}{l}37.92 \\
\pm 0.68\end{array}$ & $\begin{array}{l}40.67 \\
\pm 0.70\end{array}$ & $\begin{array}{l}42.67 \\
\pm 0.86\end{array}$ & $\begin{array}{l}45.25 \\
\pm 0.91\end{array}$ & $\begin{array}{l}37.66 x \\
\pm 0.72\end{array}$ & \multirow{2}{*}{$\begin{array}{c}0.03^{\star} \text { (between } \\
\text { Season) and } \\
0.00^{\star} \\
\text { (between } \\
\text { Summer, } \\
\text { Winter) }\end{array}$} \\
\hline & Winter & $\begin{array}{l}25.83 \\
\pm 0.59\end{array}$ & $\begin{array}{l}31.92 \\
\pm 1.10\end{array}$ & $\begin{array}{r}39.00 \\
\pm 0.80 \\
\end{array}$ & $\begin{array}{l}39.67 \\
\pm 0.80\end{array}$ & $\begin{array}{l}39.92 \\
\pm 0.60\end{array}$ & $\begin{array}{l}41.00 \\
\pm 0.65\end{array}$ & $\begin{array}{l}42.00 \\
\pm 0.97\end{array}$ & $\begin{array}{l}37.05 y \\
\pm 0.67\end{array}$ & \\
\hline \multirow{2}{*}{$\begin{array}{l}\text { Linear Length } \\
\quad(\mathrm{cm})\end{array}$} & Summer & $\begin{array}{l}26.83 \\
\pm 0.44\end{array}$ & $\begin{array}{l}28.08 \\
\pm 1.13\end{array}$ & $\begin{array}{l}33.00 \\
\pm 0.69\end{array}$ & $\begin{array}{l}33.92 \\
\pm 0.58\end{array}$ & $\begin{array}{l}34.92 \\
\pm 0.76\end{array}$ & $\begin{array}{l}37.17 \\
\pm 0.79\end{array}$ & $\begin{array}{l}38.75 \\
\pm 0.57\end{array}$ & $\begin{array}{l}33.24 \\
\pm 0.52\end{array}$ & \multirow{2}{*}{$\begin{array}{c}0.77 \text { (between } \\
\text { Season) and } \\
0.00^{\star} \\
\text { (between } \\
\text { Summer, } \\
\text { Winter) }\end{array}$} \\
\hline & Winter & $\begin{array}{l}24.42 \\
\pm 0.75\end{array}$ & $\begin{array}{l}28.42 \\
\pm 1.74\end{array}$ & $\begin{array}{l}33.83 \\
\pm 0.55\end{array}$ & $\begin{array}{l}35.25 \\
\pm 0.39\end{array}$ & $\begin{array}{l}34.25 \\
\pm 0.62\end{array}$ & $\begin{array}{l}37.50 \\
\pm 0.95\end{array}$ & $\begin{array}{l}38.50 \\
\pm 0.89\end{array}$ & $\begin{array}{l}33.17 \\
\pm 0.62\end{array}$ & \\
\hline
\end{tabular}

Means having different superscript in the last column $(p, q)$ for the specific parameter differ significantly** $P \leq 0.01,{ }^{*} P \leq 0.05$ 
Table 2: Mean with standard error of Physiological parameters of Summer and Winter born black Bengal goats during pre-pubertal growth period

\begin{tabular}{|c|c|c|c|c|c|c|c|c|c|c|}
\hline Parameters & Sex & G1 & G2 & G3 & G4 & G5 & G6 & G7 & Overall & P Value \\
\hline \multirow{2}{*}{$\begin{array}{c}\text { Rectal } \\
\text { Temperatur } \\
e \\
\left({ }^{\circ} \mathrm{C}\right)\end{array}$} & Summer & $\begin{array}{l}39.04 \\
\pm 0.13\end{array}$ & $\begin{array}{l}39.33 \\
\pm 0.21\end{array}$ & $\begin{array}{l}39.38 \\
\pm 0.18\end{array}$ & $\begin{array}{l}39.42 \\
\pm 0.28\end{array}$ & $\begin{array}{l}39.42 \\
\pm 0.29\end{array}$ & $\begin{array}{l}39.33 \\
\pm 0.26\end{array}$ & $\begin{array}{l}39.46 \\
\pm 0.27\end{array}$ & $\begin{array}{l}39.34 x \\
\pm 0.09\end{array}$ & \multirow{2}{*}{$\begin{array}{l}0.00^{* *}(\mathrm{~b} \\
\text { etween } \\
\text { season) }\end{array}$} \\
\hline & Winter & $\begin{array}{l}38.50 \\
\pm 0.15\end{array}$ & $\begin{array}{l}38.50 \\
\pm 0.15\end{array}$ & $\begin{array}{l}38.75 \\
\pm 0.14\end{array}$ & $\begin{array}{l}38.79 \\
\pm 0.18\end{array}$ & $\begin{array}{l}38.75 \\
\pm 0.14\end{array}$ & $\begin{array}{l}38.83 \\
\pm 0.18\end{array}$ & $\begin{array}{l}38.63 \\
\pm 0.20\end{array}$ & $\begin{array}{l}38.68 y \\
\pm 0.06\end{array}$ & \\
\hline \multirow{2}{*}{$\begin{array}{l}\text { Pulse rate } \\
\text { (No./min) }\end{array}$} & Summer & $\begin{array}{r}115.17 \\
\pm 0.75 \\
\end{array}$ & $\begin{array}{l}110.67 \\
\pm 1.06 \\
\end{array}$ & $\begin{array}{r}115.67 \\
\pm 1.08 \\
\end{array}$ & $\begin{array}{c}107.33 \\
\pm 1.9 \\
\end{array}$ & $\begin{array}{l}106.08 \\
\pm 2.06 \\
\end{array}$ & $\begin{array}{r}103.75 \\
\pm 1.50 \\
\end{array}$ & $\begin{array}{l}108.67 \\
\pm 1.49 \\
\end{array}$ & $\begin{array}{c}109.62 x \\
\pm 0.70 \\
\end{array}$ & \multirow{2}{*}{$\begin{array}{l}0.00^{* *}(\mathrm{~b} \\
\text { etween } \\
\text { season) }\end{array}$} \\
\hline & Winter & $\begin{array}{c}111.08 \\
0.58\end{array}$ & $\begin{array}{l}111.75 \\
\pm 0.68\end{array}$ & $\begin{array}{l}111.08 \\
\pm 0.70\end{array}$ & $\begin{array}{l}103.92 \\
\pm 1.94\end{array}$ & $\begin{array}{l}106.50 \\
\pm 1.38\end{array}$ & $\begin{array}{l}97.58 \\
\pm 1.77\end{array}$ & $\begin{array}{l}97.17 \\
\pm 1.48 \\
\end{array}$ & $\begin{array}{c}105.58 y \\
\pm 0.80 \\
\end{array}$ & \\
\hline \multirow{2}{*}{$\begin{array}{l}\text { Respiratory } \\
\text { rate } \\
\text { (No./min) }\end{array}$} & Summer & $\begin{array}{l}17.08 \\
\pm 0.47 \\
\end{array}$ & $\begin{array}{l}19.08 \\
\pm 0.56 \\
\end{array}$ & $\begin{array}{l}19.92 \\
\pm 0.47 \\
\end{array}$ & $\begin{array}{l}19.75 \\
\pm 0.46 \\
\end{array}$ & $\begin{array}{l}19.92 \\
\pm 0.43 \\
\end{array}$ & $\begin{array}{l}19.08 \\
\pm 0.48 \\
\end{array}$ & $\begin{array}{l}19.58 \\
\pm 0.47 \\
\end{array}$ & $\begin{array}{l}19.20 \mathrm{x} \\
\pm 0.20 \\
\end{array}$ & \multirow{2}{*}{$\begin{array}{c}0.00^{* *}(\mathrm{~b} \\
\text { etween } \\
\text { season })\end{array}$} \\
\hline & Winter & $\begin{array}{l}13.67 \\
\pm 0.47\end{array}$ & $\begin{array}{l}13.58 \\
\pm 0.53\end{array}$ & $\begin{array}{l}12.17 \\
\pm 0.51\end{array}$ & $\begin{array}{l}13.17 \\
\pm 0.59\end{array}$ & $\begin{array}{l}12.83 \\
\pm 0.58\end{array}$ & $\begin{array}{l}12.75 \\
\pm 0.52\end{array}$ & $\begin{array}{l}12.58 \\
\pm 0.53\end{array}$ & $\begin{array}{l}12.96 y \\
\pm 0.20\end{array}$ & \\
\hline
\end{tabular}

Means having different superscript in the last column $(p, q)$ for the specific parameter differ significantly** $P \leq 0.01$

Table 3: The correlation coefficients between the Growth parameters and Physiological responses of black Bengal goat during Summer in pre-pubertal state

\begin{tabular}{|c|c|c|c|c|c|c|c|}
\hline & Body weight & $\begin{array}{c}\text { Average } \\
\text { weight gain }\end{array}$ & Height & Heart girth & $\begin{array}{l}\text { Linear } \\
\text { length }\end{array}$ & $\begin{array}{c}\text { Rectal } \\
\text { Temperature } \\
\end{array}$ & $\begin{array}{l}\text { Pulse } \\
\text { Rate }\end{array}$ \\
\hline $\begin{array}{l}\text { Average weight } \\
\text { gain }\end{array}$ & $0.264^{*}$ & & & & & & \\
\hline Height & $0.875^{* *}$ & 0.145 & & & & & \\
\hline Heart girth & $0.865^{* *}$ & 0.112 & $0.942^{* *}$ & & & & \\
\hline Linear length & $0.862^{\star \star}$ & 0.171 & $0.897^{* *}$ & $0.901^{* *}$ & & & \\
\hline $\begin{array}{c}\text { Rectal } \\
\text { Temperature }\end{array}$ & 0.159 & 0.091 & 0.182 & $0.231^{*}$ & 0.200 & & \\
\hline Pulse Rate & $-0.346^{* *}$ & -0.031 & $-0.269^{*}$ & -0.173 & $-0.225^{\star}$ & 0.120 & \\
\hline Respiration Rate & $0.295^{* *}$ & 0.074 & $0.490^{* *}$ & $0.551^{* *}$ & $0.480^{* *}$ & $0.359^{* *}$ & 0.166 \\
\hline
\end{tabular}

Table 4: The correlation coefficients between the Growth parameters and Physiological responses of black Bengal goat during Winter in pre-pubertal state

\begin{tabular}{|c|c|c|c|c|c|c|c|}
\hline & $\begin{array}{l}\text { Body } \\
\text { weight }\end{array}$ & $\begin{array}{c}\text { Average } \\
\text { weight gain }\end{array}$ & Height & Heart girth & $\begin{array}{l}\text { Linear } \\
\text { length }\end{array}$ & $\begin{array}{c}\text { Rectal } \\
\text { Temperature }\end{array}$ & $\begin{array}{l}\text { Pulse } \\
\text { Rate }\end{array}$ \\
\hline Average weight gain & -0.008 & & & & & & \\
\hline Height & $0.911^{\star \star}$ & -0.072 & & & & & \\
\hline Heart girth & $0.760^{\star \star}$ & -0.069 & $0.843^{\star \star}$ & & & & \\
\hline Linear length & $0.811^{\star *}$ & -0.041 & $0.866^{\star \star}$ & $0.867^{* *}$ & & & \\
\hline Rectal Temperature & 0.124 & -0.093 & 0.131 & 0.208 & 0.116 & & \\
\hline Pulse Rate & $-0.617^{\star *}$ & 0.075 & $-0.549^{* *}$ & $-0.523^{\star \star}$ & $-0.495^{\star *}$ & -0.206 & \\
\hline Respiration Rate & -0.185 & -0.020 & -0.096 & -0.128 & -0.205 & 0.006 & 0.092 \\
\hline
\end{tabular}


Table 5: Simple Regression equations between age as independent variable and other dependable variables studied for kid born in Summer season

\begin{tabular}{|c|c|c|c|}
\hline Sl. No. & \multicolumn{2}{|c|}{ Equation } & $\mathrm{R}^{2}$ value \\
\hline 1 & Body weight & $=1.13 \mathrm{Age}+0.12$ & $0.99^{\star \star}$ \\
\hline 2 & Height & $=2.58 \mathrm{Age}+24.12$ & $0.91^{\star \star}$ \\
\hline 3 & Heart Girth & $=2.89 \mathrm{Age}+26.08$ & $0.88^{\star \star}$ \\
\hline 4 & Linear Length & $=1.99 \mathrm{Age}+25.26$ & $0.95^{\star \star}$ \\
\hline 5 & Haemoglobin Concentration & $=0.43 \mathrm{Age}+8.83$ & $0.68^{\star}$ \\
\hline 6 & Blood Glucose & $=-5.08 \mathrm{Age}+72.93$ & $0.91^{\star \star}$ \\
\hline 7 & Total Protein & $=0.20 \mathrm{Age}+6.25$ & $0.64^{\star}$ \\
\hline 8 & Globulin & $=0.09 \mathrm{Age}+3.36$ & $0.59^{\star}$ \\
\hline 9 & Albumin & $=0.11 \mathrm{Age}+2.89$ & $0.65^{\star}$ \\
\hline 10 & Plasma Total Cholesterol & $=-10.21 \mathrm{Age}+144.36$ & $0.81^{\star \star}$ \\
\hline 11 & Aspartate Aminotransferase & $=4.15 \mathrm{Age}+64.63$ & $0.63^{\star}$ \\
\hline 12 & Alanine Aminotransferase & $=1.35 \mathrm{Age}+17.22$ & $0.77^{\star \star}$ \\
\hline 13 & $\alpha-$ Amino Nitrogen & $=4.81 \mathrm{Age}+8.28$ & $0.96^{\star \star}$ \\
\hline 14 & Non-esterified Fatty Acids & $=7.30 \mathrm{Age}+47.08$ & $0.99^{\star \star}$ \\
\hline 15 & Plasma Sodium & $=-2.49 \mathrm{Age}+136.97$ & $0.89^{\star \star}$ \\
\hline 16 & Plasma Calcium & $=0.36 \mathrm{Age}+8.69$ & $0.94^{\star \star}$ \\
\hline 17 & Plasma Iron & $=0.04 \mathrm{Age}+1.20$ & $0.75^{\star \star}$ \\
\hline
\end{tabular}

$\star * P \leq 0.01$ and ${ }^{*} P \leq 0.05$

Table 6: Simple Regression equations between age as independent variable and other dependable variables studied for kid born in Winter season

\begin{tabular}{|c|c|c|c|}
\hline Sl. No. & \multicolumn{2}{|c|}{ Equation } & $R^{2}$ value \\
\hline 1 & Body Weight & $=1.15 \mathrm{Age}+0.37$ & $0.99^{\star \star}$ \\
\hline 2 & Height & $=2.47 \mathrm{Age}+24.89$ & $0.96^{\star \star}$ \\
\hline 3 & Heart Girth & $=2.41 \mathrm{Age}+27.39$ & $0.77^{\star \star}$ \\
\hline 4 & Linear Length & $=2.17 \mathrm{Age}+24.48$ & $0.87^{\star \star}$ \\
\hline 5 & Pulse Rate & $=-2.67 \mathrm{Age}+116.25$ & $0.84^{\star \star}$ \\
\hline 6 & Haemoglobin Concentration & $=0.43 \mathrm{Age}+9.28$ & $0.85^{\star \star}$ \\
\hline 7 & Total Erythrocyte Count & $=0.27 \mathrm{Age}+12.47$ & $0.69^{*}$ \\
\hline 8 & Blood Glucose & $=-4.69 \mathrm{Age}+75.00$ & $0.75^{\star \star}$ \\
\hline 9 & Total Protein & $=0.17 \mathrm{Age}+6.61$ & $0.87^{\star \star}$ \\
\hline 10 & Globulin & $=0.13 \mathrm{Age}+3.23$ & $0.70^{*}$ \\
\hline 11 & Plasma Total Cholesterol & $=-9.59 \mathrm{Age}+144.58$ & $0.76^{\star \star}$ \\
\hline 12 & Aspartate Aminotransferase & $=3.94 \mathrm{Age}+68.46$ & $0.63^{\star}$ \\
\hline 13 & Alanine Aminotransferase & $=1.16 \mathrm{Age}+19.60$ & $0.84^{\star \star}$ \\
\hline 14 & $\alpha$-Amino Nitrogen & $=4.96 \mathrm{Age}+8.49$ & $0.97^{\star \star}$ \\
\hline 15 & Non-esterified Fatty Acids & $=7.90 \mathrm{Age}+43.42$ & $0.98^{\star \star}$ \\
\hline 16 & Plasma Sodium & $=-2.63 \mathrm{Age}+140.58$ & $0.99^{\star \star}$ \\
\hline 17 & Plasma Potassium & $=0.08 \mathrm{Age}+6.77$ & $0.76^{\star \star}$ \\
\hline 18 & Plasma Calcium & $=0.22 \mathrm{Age}+9.54$ & $0.70^{\star}$ \\
\hline 19 & Plasma Iron & $=0.05 \mathrm{Age}+1.13$ & $0.68^{\star}$ \\
\hline
\end{tabular}

